logos_i_ethos_2019_special issue,pp.175-199

DOI: http://dx.doi.org/10.15633/lie.3474

Maciej Manikowski

ORCID: https://orcid.org/0000-0002-8278-5475

\title{
Dialogicity of faith: Tomáš Halík, Joseph Ratzinger and Józef Tischner
}

It is in a remarkably transparent manner that the Catechism of the Catholic Church emphasises the dialogic character of faith when it says: "Faith is a personal act - the free response of the human person to the initiative of God who reveals himself." ${ }^{\prime}$ However, this statement of the Magisterium is in a way an outcome of the teaching that can be found in some previous passages

Maciej Manikowski (b. 1966) - a graduate of philosophy from the University of Wrocław, an individual course of theological study (during scholar internships) in Rome, Leuven and Bochum, a doctor of philosophy with a habilitation degree, an assistant professor at the Unit of Philosophical Anthropology at the Institute of Philosophy, University of Wrocław. He specialises in philosophy of dialogue, philosophical anthropology, Russian philosophy, fundamental theology, theology of the Holy Trinity and medieval mysticism. in the Catechism. There, faith is referred to as an "adequate response to God's invitation" (142), as "man's personal adherence to God" (150) and as "an authentically human act" (154). All these statements emphasise the distinctly human and personal dimension of faith, but also its dialogic character by stressing the two elements as two indispensable shores connected by a bridge, that is faith: God and man. Faith as a personal act carries consequences in the form of respect for human freedom. By referring to the Second Vatican Council's declaration Dignitatis humanae, the Catechism states that "man's response to God in faith must be free" (Dignitatis humanae, 10). It is exactly through this "free response" that faith becomes truly human, personal.

1 Catechism of the Catholic Church, 166 (hereinafter: CCC). A quote from: Catechism of the Catholic Church, http://www.vatican.va/archive/ENG0015/_INDEX.HTM. 
As faith is referred to as dialogue, or an encounter, emphasis is laid on its relational character. ${ }^{2}$ On the one hand, one might refer to the classical literature on the philosophy of dialogue, in Poland particularly to the works by Rev. Józef Tischner, as well as to the phenomenological tradition of philosophy, in which it is worth mentioning Bernhard Welte, a German philosopher and theologian of religion. But there are two more authors for whom the dialogic perception of faith is of a fundamental significance, even though they do not declare it in the sphere of systematic philosophy, but theology, or theological essay writing; these are Joseph Ratzinger and Tomáš Halík. In their texts one can find clear - although sometimes only indirect - references to dialogic thinking, which is arguably the effect of their being extraordinarily well-read in philosophical and theological literature. As one regards these texts, one can discern a peculiar encounter between the three intellects - the Cracow-based philosopher of an encounter, the German theologian, today's Pope Benedict XVI, and the Czech theologian, philosopher, sociologist, specialist in religious studies, one of the spiritual leaders of the Velvet Revolution.

As I attempt to define faith as dialogue or an encounter, thereby emphasising its dialogic character, I would like to follow two paths which will make it possible to more clearly understand that which for faith is - to use Bernhard Welte's expression - of the essence. The first moment is the one of determining that which we call faith as faith, that is the attempt at understanding that which is the essence of faith. The second moment is the one of showing the essential character of the act of faith, where the

2 The present text is a modified, amended and extended version of the paper delivered during Colloquia Tischneriana Wratislaviensia in Wrocław, 6 April 2011, and till now it has not been published. The text is generally concerned with the thought of the Czech philosopher and theologian, as juxtaposed with the thought of Joseph Ratzinger and Józef Tischner. Hence, I have decided to extensively quote, if the text requires that, statements by Thomas of Prague, as Archbishop Józef Życiński would refer to him. The present text is not intended to be a comprehensive and exhaustive discussion of Halík's thought, much less the thought of Joseph Ratzinger or Józef Tischner. It is merely a certain attempt at or an invitation to the discussion of the question of dialogicity of faith. Cf. also my first text on this issue: M. Manikowski, Wiara jako relacja odniesienia człowieka do Boga, [in:] Filozofia religii, ed. J. Baniak, Poznań 2006, vol. 2, pp. 15-31. 
dialogic approach plays a crucial role, in my opinion. But before I move on to these deliberations, I want to stop for a moment to point to the difference between religion and faith, because these days a synonymous understanding of these two terms is quite common, which often happens in the context of the deliberation on the so-called religious revival.

\section{Religion and faith}

An attempt at showing the differences between religion and faith does not have to result in their marked contrast, but only in bringing into relief that which makes them different, and yet not necessarily disparate. Tomáš Halík writes about this differentiation in a highly evocative manner:

Systems of religious convictions are a "wardrobe" of faith, reflecting the taste and style of particular eras and cultures that faith undergoes. Religion is a depth structure of society and its culture; religion builds and integrates the human world faith crosses walls. Religion is a home environment which a man enters when he is born; faith is a matter of choice, decision, a free response to the call - and taking to the road. ${ }^{3}$

Thus, Tomáš Halík emphasises that religion (or better its cult manifestation) is a kind of housing for that which is faith, a man's existential attitude to God, the world and man; religion is that which is formed by culture and society, in which faith lives its own life; faith is an existential posture, a posture of decision, free choice, taking to the road, or - simply enough - crossing the boundaries (I will return to the perception of faith as the road later on). As he regards faith in the context of this opposition to religion, Tomáš Halík writes elsewhere:

3 T. Halík, Co nie jest chwiejne, jest nietrwałe. Labiryntem świata z wiarą i wątpliwościami, trans. J. Zychowicz, Kraków 2004, p. 115. 
Faith is a man's free response to God's call. Religion is a matter of tradition, community, authority - faith presupposes personal conversion and transformation, metanoia; strictly speaking, "faith" cannot be inherited. ${ }^{4}$

Therefore, faith is something else than religion, although both the realities are inextricably linked. As he stresses the differences, as well as that which the two have in common, Tomáš Halík points to the dialogic character of faith. Let me quote his words, treating them here as a very handy introduction to the main point of this text:

In such an approach faith is not a set of metaphysical convictions, but comes to be expressed in our relation to all reality. I have faith whenever my attitude towards the world is not manipulative, or "monologic," but a dialogic one, which (at least subconsciously, implicite) presupposes and contains a relation to the horizon of the "absolute You."

As Joseph Ratzinger tries to theologically elucidate the notions of faith and religion, which he does in the context of the clarification of the position of theological exclusivism, he directs his deliberations towards pointing to the essence of Christianity and its attitude to world religions. He writes:

It seems to me that the primary postulate with regard to the varied theology of religion is that the terms "faith" and "religion" be elucidated, because both are vague, and they are confused as often as they are generalised. That is why we speak about "faiths" in the plural, thinking about all religions, although the concept of "faith" does not feature in all religions, or at least it is not constitutive for all of them, and if it does feature, its perceptions differ. And conversely - the term 'religion' became

4 Idem, Wzywany czy niewzywany Bóg się tutaj zjawi. Europejskie wykłady z filozofii i socjologii dziejów chrześcijaństwa, trans. A. Babuchowski, Kraków 2006, p. 99.

5 Ibidem, p. 107; emphasis added - M. M. 
extended and began to be used as a general name of man's attitude towards Transcendence only in the second half of the modern times. ${ }^{6}$

In the context of Cardinal Ratzinger's quoted thought, that which assumes the greatest importance here can be expressed in the following words: faith can be manifested in man's life as religion (it is worth invoking Halík's "wardrobe of faith" here), but it does not always have to come down to religion.

Joseph Ratzinger's observation appears to be quite obvious at the starting point - one should not blindly view the denotations of faith and religion as equivalent. Commonsensical reasoning is enough to discern that they denote different, though not entirely opposing things. Of course, there remain some serious questions which concern both faith and religion, their mutual relation, and that which for them is theologically and philosophically essential. However, Cardinal Ratzinger's words at the end of the quoted passage are particularly noteworthy. On the one hand, he speaks about religion that takes into account man's attitude towards Transcendence, but on the other hand he clearly emphasises that the extension of the perception of religion is a product of the modern times. It appears that this remark serves to highlight the crucial moment when the scope of what we perceive faith to be and the scope of what we perceive religion to be begin to overlap and mesh. And so the time has come to ponder the major problem: What is - in its essence - faith?

\section{Faith is not knowledge}

Such a question can be approached in a twofold manner, as one can try and define faith by negative means, thereby characterising it through the prism of what it is not, but one might also attempt a positive description

${ }^{6}$ J. Ratzinger, Wiara - prawda - tolerancja. Chrześcijaństwo a religie świata, trans. R. Zajączkowski, Kielce 2005, p. 42. These reflections emerge in the context of a polemic with Karl Barth's theology. Because in the text I refer to texts written mainly before 2005, I will be consistently using the surname Ratzinger, and only whenever the need arises, I will use the name Benedict XVI. 
whereby we would be made to look for the characteristics constituting the definition (though we do not always need to think about a definition in the strict sense). It is not my intention to comprehensively address the original issue in such a short text, as it is only possible to make do with certain guidelines.

Negative characterisation of faith always takes the form of considering it in relation to knowledge. Man's activity in the world is marked by certain bipolarity - on the one hand, there are areas with the predominance of knowledge, and along with it - certainty, while on the other hand, in many moments in life knowledge is replaced with faith, to be more precise: everyday life faith. Joseph Ratzinger describes it like this:

We live surrounded by things we do not really know, but we place in them trust based on our experiences, which in most cases are positive. "We believe" that they are trustworthy, and thanks to this "faith we can partake in other people's knowledge. (...) On the one hand, this kind of faith is necessary in our lives. Nothing could work without it and everyone would have to begin at the beginning. Human life becomes impossible if man cannot trust their experience, their knowledge and the things he hears from them. That is one of the aspects of this faith - the positive aspect. On the other hand - such faith is a manifestation of ignorance and in this sense it is a secondary basis: it would be better for us to know. ${ }^{7}$

\section{Tomáš Halík adds:}

Let us remember that Karl Popper, one of the classics of the contemporary critical rationalism, openly admits that his rationalism is based on faith as the last resort, which he himself clearly refers to as his "irrational faith in reason." Many people who are totally indifferent about any religions base not only a number of their own convictions, but also major decisions and outlooks on life on trust-inspired faith, rather than on something that they have empirically tested or logically proven. ${ }^{8}$

7 Idem, Patrzeć na Chrystusa, trans. J. Merecki, Kraków, p. 10.

8 T. Halík, Co nie jest chwiejne..., op. cit., p. 165. 
The presented excerpts from texts by Joseph Ratzinger and Tomáš Halík refer us to two aspects. The first one is a practical dimension, which is perhaps most clearly emphasised by Halík when he refers to the aspect of our "life decisions." Without trust, trust in other people's knowledge, and without this trust which after all is our everyday life faith, man's operation in the world would be severely hampered, if not absolutely impossible. If we could not rely on trust in others, then everyday we would have to make decisions on the basis of our own - more often than not very scanty - knowledge, our own empirical experiences or reflections. But we are fortunate in that we can rely on other people's knowledge, and trust in their experience and knowledge, thus making our everyday existence in the world easier. Therefore, our-being-in-the-world is based on trust, mutual trust, on the community of confidence and the community of participation in the understanding of the world, but on the other hand it is also based on straightforward acceptance of the fact that that is something insufficient, temporary, preliminary, and that it is merely the first step in the direction of knowledge, if only we choose to make the effort to gain knowledge. The structure of knowledge thus construed is - as Cardinal Joseph Ratzinger points out - of a threefold character:

We can now list the elements that make up this faith (the elements that its "structure" is composed of). The elements are three in number. Firstly, this kind of faith always refers to someone who "knows": it presupposes real knowledge possessed by individuals with proper preparation and worthy of faith. The second element is the trust of many people who, while using a number of things every day, rely on the accuracy of the knowledge that underlies them. The third element is a certain kind of verification of knowledge in everyday experience. ${ }^{9}$

Thus presented, faith, which by the Bavarian theologian is referred to as everyday life faith, shows that which appears to be fundamental: even though everyday life faith is connected with knowledge (and in particular other people's knowledge), in itself and as such it is not knowledge.

9 Ibidem, pp. 11-12. 
Noteworthily, and this in a way results from the above, faith cannot actually be learnt, unlike any other knowledge. Joseph Ratzinger suggests the answers:

Faith in God is not a form of knowledge - in the sense of chemistry or mathematics, which I can learn - but remains faith. That means: faith has a rational structure (...). It is not some kind of an obscure thing that I would have to just accept. Faith affords me insight. And it is supported by a sufficient number of arguments that I can gain insight into. But faith will never become pure knowledge. Faith turns to all existence, will, love, self-sacrifice, and that is why it always requires that knowledge and evidence are surpassed. And since that is the case, I can always live away from knowledge and be looking for arguments to refute it. ${ }^{10}$

Further on, as if to finish off the previously begun thought, the Bavarian theologian adds:

Unlike any mathematical formula, faith cannot be understood, and it never becomes absolutely transparent to me - faith penetrates ever deeper layers, the infinity of God, the mystery of love. In this sphere purely mental understanding comes up against a boundary. As a limited being, I am not able to understand everything or fully explore it with my reason. ${ }^{11}$

If we wanted to treat faith as something that can be learnt, we would easily end up reducing it to ideology. Tomáš Halík emphasises the following: "It [faith - M. M.] is not an ideology that might serve as a tool to gain power, nor is it a sure-fire recipe for victory in the battle between competing interests," 12 and by referring to Joseph Ratzinger's thought, he adds:

10 Bóg i świat. Wiara i życie w dzisiejszych czasach. Z kardynałem Josephem Ratzingerem rozmawia Peter Seewald, trans. G. Sowinski, Kraków 2001, p. 28.

11 Ibidem, p. 42.

12 T. Halík, Dotknij ran. Duchowość nieobojętności, trans. A. Babuchowski, Kraków 2010, p. 167. 
The way I understand it, in the spirit of the biblical prophets and great Christian (but also Judaic and Islamic) mystics and theologians, faith is not and cannot be a "theism" or any other "ism," because then it would turn into its opposite, into an ideology and idolatry, pagan worship of idols. The battle against worship of idols is a battle against the replacement of the symbol with the object it stands for. ${ }^{13}$

Hence, from the negative, apophatic perspective, faith is not knowledge, or at least it is not knowledge in the sense of exact sciences, though arguably it is not knowledge in the sense of humanities and social sciences either. Why? Because, as Joseph Ratzinger and Tomáš Halík (and probably others too) emphasise, it cannot be learnt, unlike other sciences; nor can one or does one apply the same methods of argumentation as the ones used in sciences. It is not knowledge either, because it is not wholly based on reasoning - though its rational structure cannot be denied - but on that which Cardinal Ratzinger calls insight. Such an approach to the issue makes it possible to see that which - in my opinion - is fundamental in the understanding of faith: it does not refer to reason, intuition or feelings, but to the whole man. This aspect - and let us call it here existential, though not in the sense of a specific philosophical trend - appears to be usually omitted or entirely forgotten whenever faith is analysed. Let me stress that once again, faith is not a domain of some human power, but is specific to the whole man. Let us try to look at faith from a positive perspective.

\section{Faith as entrustment}

As we consider the problem of faith, especially from the perspective of Saint Paul's theology or Kierkegaard's philosophy, we nearly automatically refer to the figure of Abraham, whom after all we call the father of faith. But Polish philosopher of an encounter Józef Tischner shows that while addressing the issue of faith, not one but two biblical figures

13 Idem, Drzewo ma jeszcze nadzieję. Kryzys jako szansa, trans. A. Babuchowski, Kraków 2010, p. 161. 
should be taken into consideration: Adam and Abraham (Tomáš Halík adds one more figure, from Greek mythology, which will be addressed further on). ${ }^{14}$

To understand the phenomenon of faith is to understand the attitude of Adam and Abraham. As Józef Tischner writes, Abraham is the one who "rectifies Adam's error." What was then Adam's error about? In one of the Stary Sącz sermons by the Cracow-based philosopher we can read the following:

In response to God's calling, Adam hid himself and did not want to show up to God. He did not believe; he did not trust. In a way Abraham rectifies Adam's error. To God's calling and to His choice, he responds with a choice. ${ }^{15}$

When God calls Adam and asks him one of the most fundamental questions in man's history: "Adam, where are you?", Adam runs off and hides in the thicket. But as he can see his own defeat, his double defeat violation of God's prohibition - eventually he decides to answer God's call, but his answer is evasive rather than one reaching deep down to the very essence of what has happened. Even though Adam decides to answer God's call, he runs away again. Abraham does a different thing. When God calls him, Abraham stands to attention and answers: "Here I am!," making his answer a model of response for every man, every man of faith. And in the combination of these two stories, or rather their theological interpretations, one can see - as Józef Tischner would say - the essence of faith, two essential characteristics of faith.

The first one is choice. God chooses man and directs His word at him. This can be seen not only in the case of Abraham, but also, or even particularly in the case of another biblical character - Moses, who was chosen by God to be the one leading Israel to the Promised Land, or in the case of the disciples chosen by Jesus Christ for missionary activity or sharing

14 Józef Tischner does likewise, mentioning Abraham and Odysseus. Cf. J. Tischner, Filozofia dramatu. Wprowadzenie, Kraków 1999, pp. 28-29, 41.

15 Idem, Wiara ze słuchania. Kazania starosądeckie 1980-1992, Kraków 2009, p. 132. 
in His Mystery (Mount of Transfiguration). But this choice, which is only a beginning, must entail that which becomes another essential characteristic of faith, namely the answer. "To the choice he responds with a choice" - observes Józef Tischner with reference to Abraham. ${ }^{16}$ Faith begins with making the choice, with the question, with the call, with asking, but it must not end with the question or the call, because it must entail an answer which is a continuation of the choice made.

Faith means fidelity. And as we speak about fidelity, we can immediately see the figure of the great father of faith: the figure of Abraham. Faithful. To be faithful means: to be the choosing one. The chosen one - the choosing one. ${ }^{17}$

And this shows that faith the way Józef Tischner understands it is a dialectic of the chosen one and the Choosing one; it is, because it must be - the link between the one who has been chosen and the One who has chosen him.

While commenting on these words, it is worth referring to another "set" of choice-making people that we can find in Tomáš Halík's works. Following French philosopher of dialogue Emmanuel Lévinas, Halík juxtaposes Abraham and Odysseus. He writes:

Faith means leaving some place, "taking to the road." "Abram trusted the Lord and set out, although he did not know where he was going." Emmanuel Lévinas mentions two different paradigms of the path of life which underpin the western culture: the story of Odysseus, who after his adventures returns to the home island of Ithaca, and Abraham, who sets off knowing that he will never return. Likewise, Moses and his people. ${ }^{18}$

The juxtaposition of Abraham and Odysseus lets us understand that which, in Halík's opinion, is most significant for faith. At the end of his

16 Ibidem, p. 132.

17 Ibidem, p. 131.

18 T. Halík, Co nie jest chwiejne..., op. cit., p. 114. 
journey, Odysseus returns home, gets back to all that is familiar to him; with regard to Abraham's journey, he sets out, leaves home and all that is familiar to him, and as he takes to the road he makes his way towards the unknown but promised by God (hence the comparison between Abraham and Moses), Faith always means for us leaving behind certainty, that which is very familiar to us and familiarised; it means leaving to meet with the Mystery. Even though it always is a journey with a destination, we can never see or know it the moment we begin wandering, but we have it in prospect as hope. It is time to see that faith thus construed takes us to another stage on the path to its elucidation.

At the same time, faith thus construed is a certain act of striving. It can be understood in two ways: methodically and existentially. Directing our thought to the track of method can be clearly seen in Cardinal Joseph Ratzinger's sustained effort to emphasise the rational character (or structure) of faith. There is not enough room here to comprehensively address the subject, which is crucial for understanding both faith itself and Ratzinger's attitude towards it. Still, it is worth quoting a remarkable passage that emphasises the perception of faith as striving. It reads as follows:

Deep down faith is querens intellectum, as the Fathers say, that is 'seeking understanding.' Understanding, and hence rational handling of the word given earlier, constitutively belongs to faith. It necessarily leads to theology. This distinguishes the Christian faith from all other religious systems, also from the perspective of the history of religion. Theology is a uniquely Christian phenomenon which results from the structure of this faith. ${ }^{19}$

It is precisely because of this aspect of seeking its understanding that faith becomes striving, because a man of faith exactly as a man of faith perforce wants to understand his faith. This striving might also be of a more existential character, that is concerning the whole man. Józef Tischner writes: 
What is faith? It is striving. One might say that in a way we are in the same river, where some are only at the beginning, close to the spring, others are halfway through, and yet others are already in the place where all rivers end - in the blue sea, in the sea next to Jesus Christ. That is what the spirit of faith is about. That is what the life of faith is about; that is what love is about. ${ }^{20}$

Faith is a road; it is a road that we all follow; a road leading in the same direction; a road that gets the whole man committed; a road that is always about being chosen and accepting the fact of being chosen. This, however, shows that faith is always of a relational character. Faith means wandering. Tomáš Halík comments on this thus: "Faith is «continuation», resembling a never-ending road in this world." ${ }^{21}$ Why is it a "never-ending road"? Because it is a road - to use Józef Tischner's words - leading to heaven, and hence in this world it never ends. That is why Halík's opinion, Abraham is a good example of not a man of religion, but a man of faith. One of the passages reads:

Abraham cannot really be a symbol of religion as a set of rituals, doctrines, orders and prohibitions, but he can be a symbol of the dynamic character of faith. Abraham is a symbol of a man that God spoke to and to whom He showed the way. Abraham's faith means setting out, taking to the road. ${ }^{22}$

Since this road is about never-ending wandering in this world, journeying into the unknown, the necessary thing according to Tomáš Halík is the virtue of patience, because without it we will not be able to persevere on the chosen road. ${ }^{23}$

20 J. Tischner, Wiara ze słuchania, op. cit., p. 171.

21 T. Halík, Cierpliwość wobec Boga. Spotkanie wiary z niewiarą, trans. A. Babuchowski, Kraków 2009, p. 23.

${ }^{22}$ Idem, Wzywany czy niewzywany..., op. cit., p. 258.

23 Cf. idem, Cierpliwość wobec Boga, op. cit., pp. 112, 192. 


\section{Faith and doubt}

In the understanding of faith as wandering - nay, journeying into the unknown, we cannot omit the immensely important issue of doubts which - in Tomáš Halík's opinion - naturally appear in the sphere of our faith. Earlier, when juxtaposing faith with science, I said that science is the sphere in which certainty predominates; by this I meant a fact of fundamental significance for the understanding of the phenomenon of faith, namely that it is always subjected to doubt. There is no faith without doubt. Why? Because it is only in the sphere of doubt - human doubt for that matter - that faith is linked with freedom. Halík writes: "God left us room for doubt so that faith would not lose the dignity of the act of free will and daring entry into the realm of the Mystery." ${ }^{24}$ This remaining in the sphere of doubt means being continually faced with questions, serious questions which sometimes damage our edifice of certainty, and yet do not have power to demolish the foundation of our faith, that is the trust in God, who chose us and whom we answered with a free act of decision. Tomáš Halík writes:

To be a person of faith does not mean to reject the burden of pressing questions forever. Sometimes it means to accept the cross of doubt and while carrying it, faithfully emulate Christ. The power of faith does not consist in having "unwavering" conviction, but in the ability to cope with hesitation, vagueness, and to bear the burden of mystery, while maintaining faithfulness and hope. (...) Here on earth, faith is not "certainty" but openness to the Inscrutable in a question, a quest, sometimes a cry, tears and protest, but also in the incessant request for trust and perseverance, in the courage not to content oneself with superficial, overly easy answers and explanations. ${ }^{25}$

24 Idem, Drzewo ma jeszcze nadzieję, op. cit., p. 16. The liberation aspect of faith is invoked by the Catechism of the Catholic Church (160).

25 Idem, Dotknij ran, op. cit., pp. 22 and 24. Cf. idem, Wzywany czy niewzywany, op. cit., pp. 23, 27. 
Halík emphasises several unusually important aspects in the understanding of faith. The first one is the one which stresses the necessity "not to content oneself" with easy solutions which always lead to becoming ossified in something that appears to be certainty, but is not, and in fact is mere running away from difficulties that crop up. Sometimes, in everyday life, it is easier to just run away and take such shelter than to grapple, with one's head held high, with one's own (precisely: own!) doubts. Another aspect is the openness of faith, openness to questions which are sometimes difficult and fundamental, but also openness to hope of finding the answer, and hence also openness to the Mystery we are approaching in faith. Faith is a struggle and - to paraphrase the words from the Book of Job - hard service, which in a way needs to allow for all slip-ups and major setbacks so that there is enough time to ponder, because only with slow headway towards the goal is there a chance of success.

\section{Faith as an answer}

Whenever in our deliberations the biblical figures of Adam and Abraham, and in particular Moses as he is standing at the foot of the Divine Mount Horeb, but also the mythical figure of Odysseus appear, there appears almost immediately the issue of the perception of faith as conversation, an encounter, dialogue. At this point it is worth taking a look at the elements that lead to faith.

Above all, it is - which has already been mentioned many times - the answer to the word that has been heard, to the summoning, because the word introduces a certain relational character into faith. German theologian and philosopher Bernhard Welte writes:

The word occurs as a relation. This relation always comes from the speaking one. It cannot be established in the opposite direction, that is towards him. This re- 
lation always comes from him and is directed at the one who is spoken to, and who wants to hear it, understand it, and in some cases it is even accepted. ${ }^{26}$

And so as we can see in Welte's text we have three spheres: the speaking one, the one spoken to and the relation which has been established between them. ${ }^{27}$ Someone directs a word to a man; it makes the one at whom it was directed the recipient, that is - to use Welte's terminology the one spoken to, and he, as he is spoken to and feels responsible for the word conveyed to him, answers it, and thus the relation becomes established. The important thing is that there is no relation until the answer has been given. In a way it is the answer to the act of being spoken to that builds the relation. When God directs His word at us, and we, like Abraham or Moses, answer it by saying "Here I am!", then as we are spoken to by God, through our answer we establish with Him a relation which can be called faith. ${ }^{28}$

However, this encounter between God and man - like an encounter between man and man - takes place in some space. Józef Tischner calls this space a 'place.'

A place gets formed wherever - he writes - a man encounters another man, or God. A man who encounters no one, who walks through the world, refusing to open up to people and their needs, closing his ears to their voices; a man who never encounters God - there is no place on earth for such a man. ${ }^{29}$

And here we can discern a crucial moment in the Cracow-based philosopher's philosophical thinking. A place is in a way secondary to the relation between man and man, or man and God. It is only this

26 B. Welte, Czym jest wiara? Rozważania o filozofii religii, trans. W. Patyna, Warszawa 2000, p. 11. Cf. idem, Filozofia religii, trans. G. Sowinski, Kraków 1996; J. Tischner, Filozofia dramatu, op. cit., pp. 101-104.

${ }^{27}$ The concept of a man called upon was originated by Ferdinand Ebner. Cf. F. Ebner, Słowo i realności duchowe. Fragmenty pneumatologiczne, trans. K. Skorulski, Warszawa 2006, pp. 12-19.

28 Cf. T. Halík, Wzywany czy niewzywany, op. cit., p. 107.

29 J. Tischner, Wiara ze słuchania, op. cit., p. 133. 
relation - the relation of the encounter - that forms a place, the space for an encounter. Without an encounter there would be no place. That is why the most fundamental place for an encounter is a church, a sacred place:

A church is a place. A place is formed wherever a man meets another man. A home is a place, because it is a place where family members meet. A church is a place, because it is a meeting place. ${ }^{30}$

We have two overlapping spheres here: on the one hand, there is the relation of word that becomes established between the speaking one and the one spoken to, and on the other hand, there is the space that gets created as a result of this encounter. And so we have a peculiar dialectic of man and space. As he refers to a very similar problem, Joseph Ratzinger writes:

For man, the remarkable thing is - when viewed from above - that God has spoken to him, and so he is a participant in dialogue, a creature called upon by God. When viewed from below, this means that man is a creature that can think about God, a creature open to transcendence. The point is not whether man really thinks about God, or opens up to Him, but the fact that essentially he is a creature capable of that even if in reality he is not able to realise this capability for any reasons. ${ }^{31}$

I believe that here Joseph Ratzinger emphasises two moments. Firstly, the very relation between God and man, and secondly, its actual or potential character. Man is capable of establishing a relation with God, that is to answer the spoken word, but it does not always have to become actualised. The causes of the non-actualisation of this capability may be manifold, one of them being the fact that in the hubbub of today's world, in the immersion in the surrounding reality we simply might not hear God's voice.

What then can be said about this relational character of faith? The first moment that is stressed here is the individuality of the act of faith, the

30 Ibidem, p. 17.

31 J. Ratzinger, Wprowadzenie w chrześcijaństwo, trans. Z. Włodkowa, Kraków 1994, p. 351. 
individuality of the answer to the directed word. If someone directs his word, he directs it at me, and not someone else. If he directs his word at me, it is only me, and not someone else, that he expects some response from. No one else but me can answer the question asked of me, because no one apart from me has been called upon to answer. When God called Adam, He directed His word at him only, when God called Abraham, $\mathrm{He}$ directed His word at him only, when God called Moses, He directed His word at him only. When God calls us, He wants our response, and $\mathrm{He}$ wants - as Józef Tischner earlier suggested - our choice. When the following question is asked: "Do you believe...," there can only be one answer: "I believe," in which the $I$ is emphasised - "I believe." As he stresses this individuality, or to put it theologically - the personhood of the act of faith, Joseph Ratzinger writes:

The act of faith is an extraordinarily personal act which is anchored in the innermost recesses of the human "I." But next to being that personal, it is also an act of communication. In its inherent nature, one's own "I" is always connected with "you" and vice versa: the authentic relation which becomes "an act of communicating" can only be generated within a person. ${ }^{32}$

This relational understanding of the act of faith reveals not only the individual, but above all the personal character of the relation as well as - consequently - the dialectic of $I$ and you. What then does it mean to be a person?

\section{Perception of the "person"}

Understanding of this theologically and philosophically significant term serves as a foundation for our understanding of faith as a relation. However, we can come closer to this understanding not through the western, Latin - originated by Augustine and Boethius - perception of the 
term, but through the Greek one originated by the Cappadocian Fathers, and today brought back by Orthodox theologian Ioannes Zizioulas. ${ }^{33}$

While studying the patristic tradition, one can discover that the perception of the person does not focus on such concepts as rationality or freedom (which is what Boethius wanted), but on such terms as relationality and relation, because it is only the communion model that can reveal that which is most important for man, to wit his being created in the image of God. Ioannes Zizioulas points out that being a person is of a distinctly ecstatic, and not only static character. What is ecstasy in this case? The Greek theologian views ecstasy as transcending oneself, that is as the ability to go beyond the fetters of one's own "I." This makes it possible to define being a person as being in a relation. To be a person means to be something more than just an individual being. In order to describe this peculiar being, this peculiarly human being, Ioannes Zizioulas adapts the Greek term of hypostasis (thereby connecting anthropology with Trinitarian theology, in which the concept of hypostasis plays a crucial role). Thus, a person is an ecstatic being, one that transcends oneself and relationally turns to other persons, at the same time being a hypostatic being, that is a carrier of nature. Thus, a person is a hypostasis, that is an individual, unique, special, exceptional and indivisible being, but at the same time an ecstasy, that is transcension of these peculiarly human characteristics. The Greek perception of the person shows that which in Latin scholars never appeared - a person "creates himself" in a sense at the intersection between being-in-oneself and being-for-others. And this stresses the dynamic character of a person. ${ }^{34}$ In a sense as a contemporary voice of the patristic sources, Tomáš Halík points out: "A human being is a human being to the extent that he is human with others and

${ }^{33}$ Orthodox theologian Ioannis Zizioulas refers in his thought to the patristic sources of the understanding of the Greek term hypostasis. However, it is noteworthy that the Western perception of man as a person through reference to the Greek term hypostasis appears in Emmanuel Lévinas. Cf. E. Lévinas, Istniejący i istnienie, tran. J. Margański, Kraków 2006, pp. 103-138.

34 Cf. J. D. Zizioulas, Human Capacity and Human Incapacity: A Theological Exploration of Personhood, „Scottish Journal of Theology”, vol. 28, no. 5, 1975, pp. 407-408. 
for others." ${ }^{35}$ These remarks by the two contemporary theologians - one Greek and one Czech - are in harmony with the above-quoted analyses by Józef Tischner and Joseph Ratzinger.

By being a hypostasis a human being becomes a nature's manner of existence, which is what later on medieval thinkers thought to be the case. A human being can exist in no other manner than as a personal being, a person in which human nature exists. This is because of itself nature cannot exist, and so it needs to have its ontological carrier, which is exactly a human person. Only a person as an ontologically special being can make nature specific in this unique and only manner. However, from the metaphysical viewpoint, a human being - as philosophical tradition has it - is a being. This refers us to the equally important question of the mutual relation between being and a person. In this aspect one needs to refer to - as Ioannes Zizioulas always puts it - the philosophical revolution in the Greek thinking which took place in the times of the Cappadocian Fathers, particularly in the metaphysical and anthropological writings by Gregory of Nyssa. Rev. Roman Małecki, when writing about Ioannes Zizioulas' theology, comments on this thus:

This relationality and openness to another are not something "added" to the essence of man. They are not accidents beautifying the "individual substance of rational nature." They are constitutive of man. Zizioulas puts it bluntly, saying that outside the community there is only a void, chaos and the "tragedy of non-actualised existence."36

The ecstatic character of a human person, remaining in a relation to others, being a communion being constitute the essence of being a person and - to use Tomáš Halík's words once again - being a human being. A person can be understood in no other way than through the prism

35 T. Halík, Dotknij ran, op. cit., p. 193.

36 Rev. R. Małecki, Komunijna prawda o człowieku, Kościele i świecie, [in:] Leksykon wielkich teologów XX i XXI wieku, ed. J. Majewski, J. Makowski, Warszawa 2004, vol. 2, p. 375. The text by Rev. Małecki is included in the entry "John Zizioulas." 
of those two distinguishing features: being a hypostasis and being an ecstasy. A human being is above all a being for another man, that is he is a person, while still remaining being, that is a hypostasis. ${ }^{37}$

Being a person lets one discern a person in another human being, or perhaps above all in another human being. Józef Tischner comments on this situation thus: "There is no and there can be no I without You, nor You without I," and then he goes on to add:

In a sense we are monads with no windows. I don't know what is going on inside you, and you don't know what is going on inside me. Still, I know that you - you for me - are I for yourself, and likewise I - I who am I for myself - am you for you. This knowledge serves as an abutment on which we can set a bridge between me and you. ${ }^{38}$

A human being discovers this special dialectic which is the essence of that which is referred to as being a human being - a human being is both I for himself and You for another human, at the same time being aware that another human being is I for himself too and You for another human, including him personally. Thus, man discovers that he is a person, not only a being in the metaphysical, individual and unique sense, just like the majority of beings in reality, but that he is also a being in the dialogic sense, that is he is always oriented towards others. Man also discovers this truth as he analyses his faith, which for him acts as a peculiar way of coming out of his own "I," out of the cycle of looping back on himself, so that he can turn to the Divine You, at the same time discovering that as he transcends his own "I" he experiences not only the truth about himself, but also the truth about God and his own faith, as well as the truth about another human being and his faith. In this way man discovers the communal character of faith.

37 Cf. M. Manikowski, „Być osobq" to „Być dla drugiego”: perspektywa teologii prawosławnej, [in:] Teologia bliźniego: obraz bliźniego a obraz Boga w religiach monoteistycznych, ed. W. Szczerba, M. Turowski, J. Zieliński, Białystok 2010, pp. 133-141. In the above discussion I am using my own thoughts precisely from that text.

38 J. Tischner, Filozofia dramatu, op. cit., pp. 107, 111. 


\section{The faith of the community}

The discovery of this dialectic I - You, the discovery of one's own personal foundation results in understanding the ontology of human being, which is both a hypostasis and an ecstasy, a being that is both individual and oriented towards others. Therefore, a human being can function in the world in no other way than as a being who turns to others. And that is also the way in which he should understand his own faith. Faith, which is an act of stepping beyond, or better: permanent stepping beyond one's own "I," is at the same stepping in the community, the communion of persons perceived in imitation of the Persons of the Holy Trinity (because man was originally created in the image of God, in the image of the Holy Trinity). And this means that faith, which is a relation between man and God, is at the same time a relation between man and man. Cardinal Joseph Ratzinger points out: "A relationship with God is also a human relationship; it is based on the community of persons, and what is more, a joint relationship with God enables deeper communication among people, which goes beyond that which is advantageous and touches a person's centre." ${ }^{39}$ A relationship with God is in a way of constitutive relevance to a relationship with another human being. Obviously, being oriented towards others is intrinsic to human being, but it is intrinsic to it, because man as the only being in the universe was created "in the image and likeness of God," which means that at the very beginning the essential relationship with God, the relation of being oriented towards his Creator was made intrinsic to him. Hence, one can say that it is only when man discovers his relationship with God, particularly in prayer, that he discovers in himself that essential relationship with another man.

Thus becomes established a community of faith, a man's shared - to use Józef Tischner's term - place in the world, because it is only in a place where a man meets another man, as well as God, that his place is. Man grows in a community like this - the community enriches him and he enriches the community with himself. At the same time he discovers that 
which is essential to that enrichment: the necessity of continual choosing. When I defined faith as an answer to the word directed at man, as a choice which is a response to a choice, I referred to the biblical figures of Abraham and Moses. Now, in the context of all that has been said so far, it is worth adding something really important. God always directs His word at us, and we are supposed to always respond to this choice. And that is not supposed to be a one-off response, but a continual one. Faith is not a one-off act of response to a call, but is an act repeated continually and every day. Bernhard Welte writes:

Every day faith needs to emerge anew, every day is a new day in its history. In spite of this, or rather because of this, faith can and will preserve its continuity. That is what faithfulness is about, and in its essence faithfulness forms part of faith. ${ }^{40}$

It is the continual iteration, continual choosing that are a foundation of faith, because in them faith gains not only its continuity, but also that which constitutes its essence: dynamism. Unrenewed faith quickly becomes dead, and not only does such faith not vivify man, but above all it does not vivify the community. Tomáš Halík comments on this thus:

Of course, we do not lose faith the way we lose a purse; it is just that one day we are surprised to find that our faith has long ceased to have any practical influence on our lives, and that our piety has gradually and imperceptibly withered away like an unwatered cyclamen in a pot outside the window. ${ }^{41}$

Unwatered flowers quickly wither. That is a very frequent experience in our everyday lives. But it teaches us that the same happens in out spiritual lives - faith is quick to wither whenever we fail to water it with our continual choosing, and our continual siding with God, our continual listening to His call, as well as our continual responding to His call. In order that we can persevere in that challenge we need the virtue

40 B. Welte, Czym jest wiara?, op. cit., p. 69; cf. J. Tischner, Wiara ze słuchania, op. cit., p. 131.

${ }^{41}$ T. Halík, Drzewo ma jeszcze nadzieję, op. cit., p. 81. 
of patience: "Indeed, faith too, if it is really faith, is patient. Nay: faith is patience." ${ }^{2}$

This discussion can be concluded with the words excerpted from Jerzy Liebert's poem entitled Rider, which are quite often quoted in Józef Tischner's Stary Sącz sermons, and which show that which is fundamental for the understanding of the dialogic character of human faith, and which for Joseph Ratzinger, Józef Tischner and Tomáš Halík is - to use the words of the latter - patience of faith:

One thing I know and no other revelations

Are needed for eyes or ears -

As I have made the choice for ages,

I need to choose at every moment.

\begin{abstract}
In the philosophical analysis of the phenomenon of faith, especially in the context of the man in whose life the faith is the response, we concluded that faith has the dialogical character, that means that faith existed only in the dialog - in the dialog with God, in the dialog with another man, in the dialog with community. The dialogical faith points that the man, like in the patristic and contemporary orthodox theology, is the being which exists only for the another, and existed in that kind it is truly the person. This is also the main thesis of the philosophy of dialogue.
\end{abstract}

\title{
Keywords
}

Dialogue, Philosophy of Faith, Christian Faith,

\section{Bibliography}

Bóg i świat. Wiara i życie w dzisiejszych czasach. Z kardynałem Josephem Ratzingerem rozmawia Peter Seewald, trans. G. Sowinski, Kraków 2001.

42 Idem, Cierpliwość wobec Boga, op. cit., p. 192. 
Catechism of the Catholic Church, Poznan 1994.

Ebner F., Stowo i realności duchowe. Fragmenty pneumatologiczne, trans. K. Skorulski, Warszawa 2006.

Halik T., Cierpliwość wobec Boga. Spotkanie wiary z niewiarą, trans. A. Babuchowski, Kraków 2009.

Halik T., Co nie jest chwiejne, jest nietrwałe. Labiryntem świata $z$ wiara $i$ wattpliwościami, trans. J. Zychowicz, Kraków 2004.

Halik T., Dotknij ran. Duchowość nieobojętności, trans. A. Babuchowski, Kraków 2010.

Halik T., Drzewo ma jeszcze nadzieję. Kryzys jako szansa, trans. A. Babuchowski, Kraków 2010.

Halik T., Wzywany czy niewzywany Bóg się tutaj zjawi. Europejskie wykłady z filozofii i socjologii dziejów chrześcijaństwa, trans. A. Babuchowski, Kraków 2006.

Levinas E., Istniejący i istnienie, trans. J. Margański, Kraków 2006.

Małecki R., Komunijna prawda o człowieku, Kościele i świecie, [in:] Leksykon wielkich teologów XX i XXI wieku, ed. J. Majewski, J. Makowski, Warszawa 2004, vol. 2.

Manikowski M., „Być osoba” to „Być dla drugiego”: perspektywa teologii prawostawnej, [in:] Teologia bliźniego: obraz bliźniego a obraz Boga w religiach monoteistycznych, ed. W. Szczerba, M. Turowski, J. Zieliński, Białystok 2010, pp. 133-141.

Manikowski M., Wiara jako relacja odniesienia człowieka do Boga, [in:] Filozofia religii, ed. J. Baniak, Poznań 2006, vol. 2. pp. 15-31.

Ratzinger J., Europa Benedykta w kryzysie kultur, trans. W. Dzierża, Częstochowa 2005.

Ratzinger J., Patrzeć na Chrystusa, trans. J. Merecki, Kraków 2005.

Ratzinger J., Prawda w teologii, trans. M. Mijalska, Kraków 2001.

Ratzinger J., Wiara - prawda - tolerancja. Chrześcijaństwo a religie świata, trans. R. Zajączkowski, Kielce 2005.

Ratzinger J., Wprowadzenie w chrześcijaństwo, trans. Z. Włodkowa, Kraków 1994.

Tischner J., Filozofia dramatu. Wprowadzenie, Kraków 1999.

Tischner J., Wiara ze stuchania. Kazania starosądeckie 1980-1992, Kraków 2009.

Welte B., Czym jest wiara? Rozważania o filozofi religii, trans. W. Patyna, Warszawa 2000.

Welte B., Filozofia religii, trans. G. Sowinski, Kraków 1996.

Zizioulas J. D., Human Capacity and Human Incapacity: A Theological Exploration of Personhood, „Scottish Journal of Theology”, vol. 28, no. 5, 1975, pp. 401-448. 